\title{
Bark Roughness as a Factor Affecting Cell Density of Epiphytic Microalgae (Apatococcus Sp)
}

\author{
Ihsan Alwi ${ }^{1}$, Siti Khairiyah Mohd Hatta ${ }^{1}$, Faeiza Buyong ${ }^{1}$, Norashirene Mohamad Jamil ${ }^{1}$, Norrizah \\ Jaffar Sidek $^{1}$, Noor Akmal Wahab ${ }^{2}$, Ahmad Ismail ${ }^{3}$ and Asmida Ismail ${ }^{1}$ \\ ${ }^{1}$ Faculty of Applied Sciences, Universiti Teknologi MARA, Shah Alam, Selangor \\ ${ }^{2}$ Department of Biology, Universiti Teknologi MARA Puncak Alam 42300, Kuala Selangor, Selangor \\ ${ }^{3}$ Faculty of Science \& Technology, Universiti Kebangsaan Malaysia, Bangi, Selangor. \\ E-mail of corresponding author: asmida@salam.uitm.edu.my
}

\begin{abstract}
Green algae are diverse and ubiquitous in aquatic and some terrestrial habitats. They play a vital role in the global ecosystems for hundreds of millions of years. Differences between trees in bark topography can cause different epiphytic variation in community composition. The objectives of this research was to assess the response of number of algal cells towards bark roughness inhabiting 15 standing trees from field collections in the Central Region of Peninsular Malaysia, Putrajaya. Several methods were involved including field sampling, algal quantification, algal identification and physical assessment of the bark roughness. The study showed that trees with rough bark sustained higher density of microalgae $\left(114{ }_{ \pm} 405 \mathrm{cells} / \mathrm{ml}\right)$ compared to the smooth ones $(1069 \pm 434 \mathrm{cells} / \mathrm{ml})$. The slight differences could be due to other physical parameters such as the degree of slope or inclination of the tree. As a conclusion, this study showed that trees with rough bark surfaces efficiently accumulates the atmospheric pollutants through its fissure and delayed water movement thus sustained more algal cells compared to trees with smooth bark.
\end{abstract}

Keywords: Bark roughness, Putrajaya, Green algae, Terrestrial algae, Alga density

\section{Introduction}

Algae are known as omnipresent organisms on earth and able to grow in an extensive variety of conditions. Despite the fact that algae are typically known from marine and freshwater natural surroundings, they likewise happen in a wide variety of terrestrial environments [1], where they conspicuous growths in a few surface types, including rocks, urban walls, metals, tree barks, leaves and animal hairs [2]. Generally regular algae that can be found in basically every kind of terrestrial environment are cyanobacteria and eukaryotic algae [3], [4]. They are likewise called terrestrial algae as in they are not dependent on liquid water [5].

Since the $19^{\text {th }}$ century, the variety of subaerial algae grow at tropical trees and leaves were investigated in different locations and habitat [6], [7]. Corticolous algae are plants from different altitude areas that grow on tree barks. They are exposed to the air and absorb water, minerals and other nutrients directly from the atmosphere.

Light and air humidity are considered as the most influential ecological factors on the growth and development of these organisms, while temperature is viewed as a secondary one [8], [9]. Bark pH of the surfaces has been considered one of the most important factors affecting the community structure of corticolous organisms [10]. The relationship between $\mathrm{pH}$ and community structure is well known for epiphytic lichens and bryophytes [11], [12] and myxomycetes [13]. The diversity of different algal groups is also influenced by light conditions [14]. Terrestrial algae have simple structures. It can efficiently accumulate the pollutant that associating with the algae. This accumulation make the algae become the good biological indicator. Aspect and inclination of tree boles also affects the degree of light exposure, but they can also influence other factors important to epiphytes

However, terrestrial microhabitats have less attention from phycologists than marine and freshwater habitats, so their diversity and community structure is still very poorly known [15], [16]. Epiphytic terrestrial green algae are the most widespread but the least known and most overlooked among all algal groups [17].

Hence, the present work has been carried out to study the effect of bark roughness towards subaerial algal density growing on tree bark. 


\section{Materials and Methods}

\subsection{Study Site}

The samples were collected from Taman Wetland, Putrajaya (geographical coordinates $\mathrm{N} 02^{\circ} 55.915$ and E101 40.909) (Figure 1).

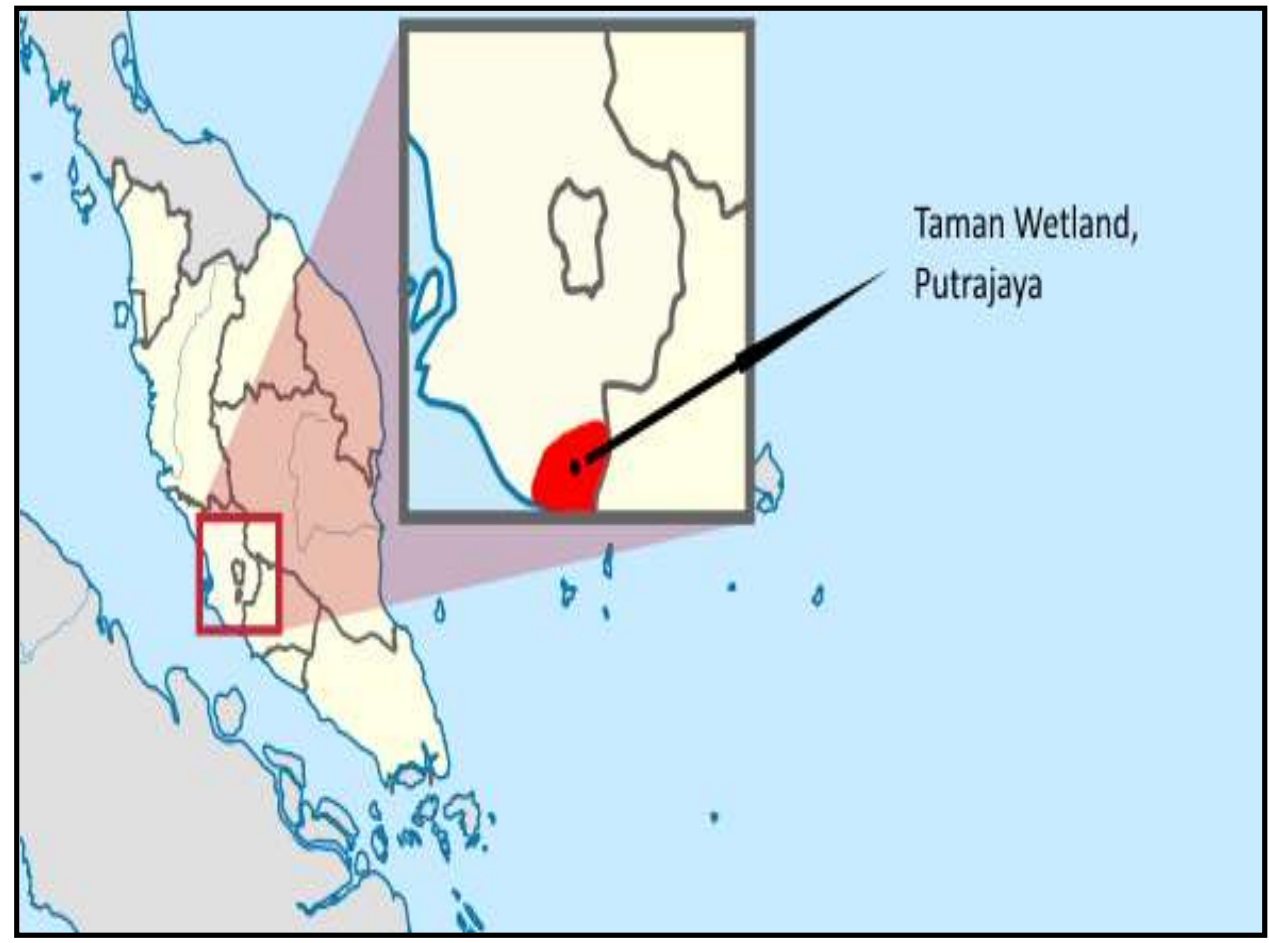

Fig. 1: Map location of the sampling site in Putrajaya

The mean annual rainfall recorded at Putrajaya is about $2,000 \mathrm{~mm}$. The rainfall pattern reflects the annual monsoon cycles. The northeast monsoon occurs from December to March with the highest rainfall recorded around November/December. The southwest monsoon occurs from June to September. The period of lowest rainfall is around June/July. The mean annual air temperature is approximately $27 \mathrm{C}$ with monthly mean air temperatures ranging from around $26 \mathrm{C}$ in December to $28 \mathrm{C}$ in May. The mean monthly minimum and maximum air temperatures range from about $20 \mathrm{C}$ to $36 \mathrm{C}$ in February, to about $22 \mathrm{C}$ to $35 \mathrm{C}$ in May.

\subsection{Sample Collection}

The bark of 15 trees with a trunk diameter of more than $10 \mathrm{~cm}$ was sampled for surface microbial growth at a height of $1.5 \mathrm{~m}$ above the soil level. Bark roughness was put into two categories (rough and smooth). Three quadrats of $10 \times 10 \mathrm{~cm}$ were placed on 15 random trees. Algae within each quadrat were collected by scraping the bark surface with wetted cotton wool and then placed in a $100 \mathrm{ml}$ sterile specimen tube containing $40 \mathrm{ml}$ deionized water. The tube specimens were shaken vigorously to loosen the algae from the wetted cotton wool. All samples were stored in a refrigerator at $1-4^{\circ} \mathrm{C}$ to prevent post-sampling growth. This study encompassed a collection of 45 tubes of algae ( 15 trees $\times 3$ quadrats).

\subsection{Sample Quantification}

Algal samples on wetted cotton wool were squeezed to ensure all algal samples were transferred into sterile specimen tube. Algal samples were then shaken vigorously to dissociate clumped algae and to separate filamentous algae into fragments [18]. For quantification process, manual quantification of algal samples was conducted. The haemocytometer chamber was used as a counting chamber of algal cells. $1 \mathrm{ml}$ of algal samples were pipetted into the well of haemocytometer and counted under light microscope. 


\subsection{Sample Identification}

A Brunel digital light microscope was used to help in identification process and to count algal cells. A digital single-lens reflex (DSLR) camera was used as an external camera to capture algal images. Then, the captured images were compared to select the best algal images to facilitate algal identification during the initial stage. Photomicrograph of the algae was compared to the images in these sources in helping the identification process. [19], [20] and database from world's algal listings (www.algaebase.org) were used as references for algal identification up to the genus level. Main goal of photomicrography was to record permanently and accurately the view of an object using digital camera.

\subsection{Bark roughness measurement}

Bark roughness was visually estimated in two ordinal categories (1: rough, 2: smooth). They mostly reflected the interspecific differences among the tree species. The sample of bark roughness as shown in Figure 2.

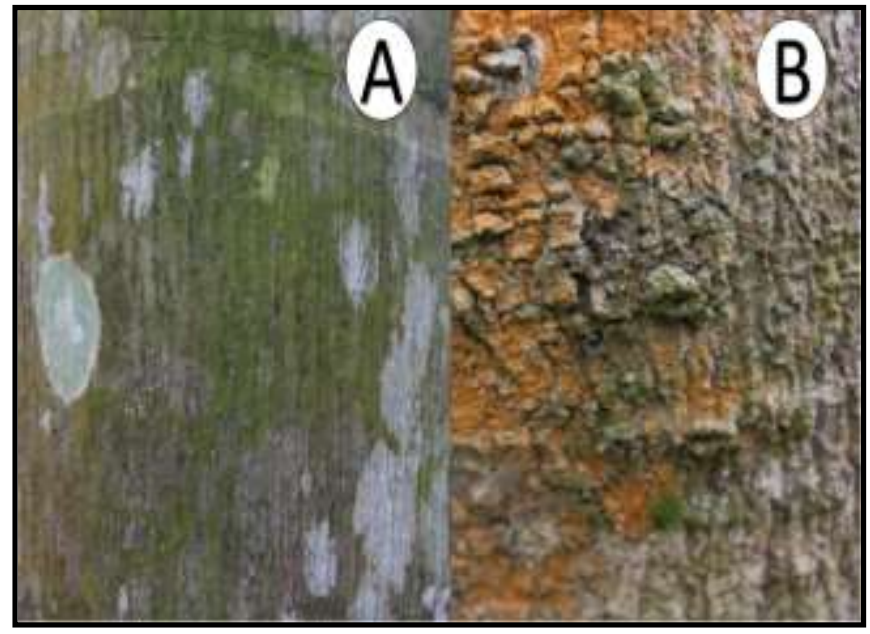

Fig 2: A. Smooth bark

B. Rough bark

\section{Result}

\subsection{Algal species}

Algae recovered from all the quadrats revealed that almost $100 \%$ were of the green alga, Apatococcus sp. Another algal species namely Trentepohlia $s p$ was also found but only in a very small quantity. Thus we considered Trentepohlia as unimportant in this study. Apatococcus $s p$ as shown in Figure 3.

Fig. 3: Apatococcus sp 


\subsection{The relationship between bark roughness and algal density}

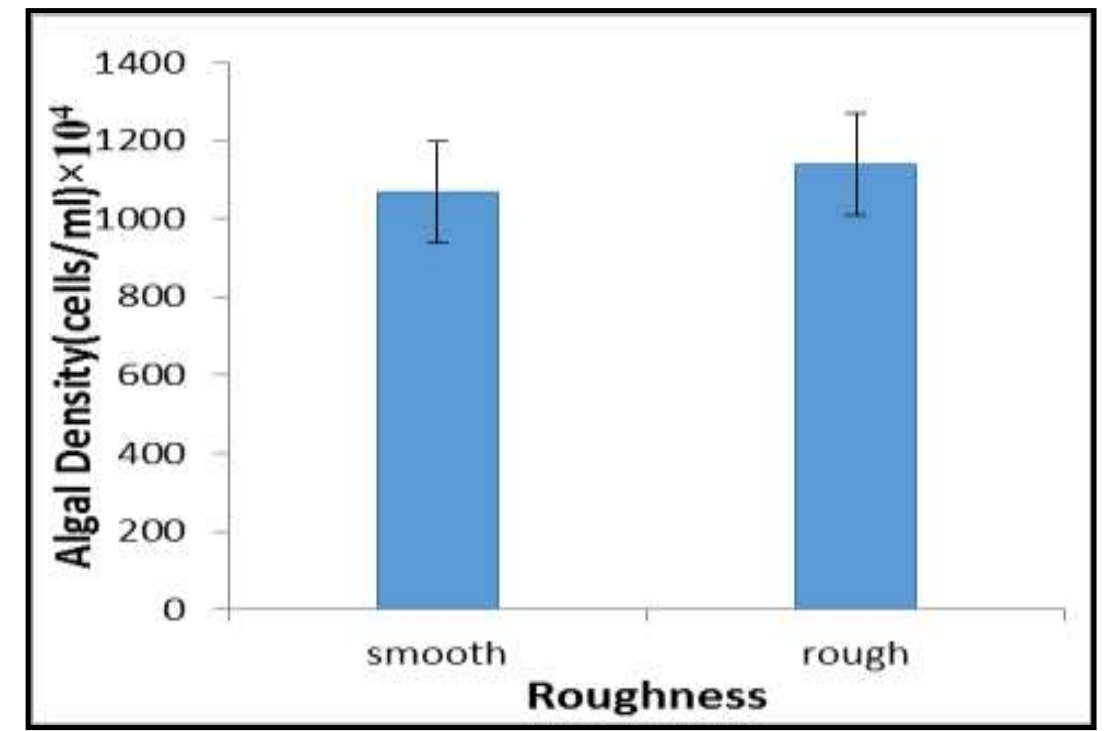

Fig. 4: Comparison of algal density between smooth bark and rough bark

From figure 4, an independent T-test was run on 15 samples to determine if there were differences in algal density based on bark roughness. Bark roughness of trees were classified into two categorical groups which smooth bark and rough bark.

There is no significant difference between algal density based on bark roughness of the trees. Although the mean of rough bark (mean $=1140$ cells $/ \mathrm{ml}$; sd=405) is higher than mean of smooth bark (mean=1069 cells $/ \mathrm{ml}$; $\mathrm{sd}=434), \mathrm{t}_{(5)}=0.29, \mathrm{p}=0.780$, , but this difference is not significant. All data were found to be normally distributed by using Normality Test.

\section{Discussion}

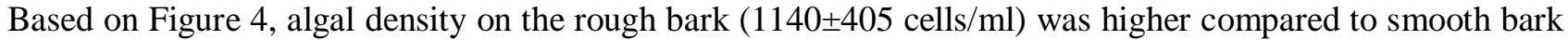
$(1069 \pm 434 \mathrm{cells} / \mathrm{ml})$ but the overlapping of error bars shows that there was no significant difference between algal density based on bark roughness.

In this study, the rough bark shows the higher mean of algal density compared to the smooth bark. The rough bark is more efficient surface structure to grasp the water and moisture from rain and dew. In the past, [21] also found that it is often visually obvious that colonization is more extensive on rough and porous surfaces than smooth, non-porous ones. Lichen studies also showed the rough bark also provides a greater opportunity for thallus fragments of lichens to embed in its surface [22].

The growth of microalgae and lichens is known to be affected by bark topography and be an important factor for lichens growth [23], [24] probably because it affects the amount of moisture received. Differences between bark topography can cause adequate epiphytic variation in community composition.

By nature, all plants will undergo the desiccation process in any conditions. Tree bark is one of the tree components where the process will occur. The smooth bark sustained less algal density probably caused by this desiccation process. Some smooth-bark can be thin, making the bark temperature sensitive and exposed to the stress of desiccation [25]. The effect of these factors means that some smooth-barked trees typically do not support diverse or rich epiphytic assemblages.

[26] found that a rough bark surface more readily accumulates atmospheric pollutants than a smooth surface. The concentration of pollutants are highest in the surface layers of the outer bark, and decrease rapidly on moving towards the inner layers of bark. The bark crevices also affect to the pollutants accumulation in tree bark. The numerous of tree crevices, the more pollutant will accumulate in rough bark crevices. Previously, [27] and [28] claims that the higher nitrogen pollutant concentrations have often been reported to increase the rate of 
algal growth. On the other hand, heavy metals and other compounds may be carried by the wind from the soil to the bark surface [29].

\section{Conclusion}

This study showed an increase of algal density on the rough bark compared to smooth bark. This result was supported by [30] which also stated that a rough surface more readily accumulates atmospheric pollutants than a smooth surface.

\section{Acknowledgement}

Authors would like express their gratitude to group members of Phycology and Aquatic Plant Laboratory (UKM) and Faculty of Applied Sciences of Universiti Teknologi Mara (UiTM) whose help and expertise has made this project a successful one. This work was funded under Research Acculturation Grant Scheme (RAGS), Ministry of Education, Malaysia and Universiti Teknologi MARA, Shah Alam, Malaysia 600-RMI/RAGS 5/3 $(8 / 2013)$.

\section{References}

[1] Hoffmann, L. 1989. Algae of terrestrial habitats. The Botanical Review, 55,177-105 http://dx.doi.org/10.1007/BF02858529

[2] Lopez-Bautista,J.M., Rindi,F. \& Guiry, M.D. 2006. Molecular systematics of the subaerial green algal order Trentepohliale: an assessment based on morphological and molecular data. International journal of Systematics and Evolutionary Microbiology, 56, 1709-1715

http://dx.doi.org/10.1099/ijs.0.63990-0

[3] Broady, P. A. 1996. Diversity, distribution and dispersal of Antarctic terrestrial algae. Biodiversity and Conservation, 5, 1307-1335

http://dx.doi.org/10.1007/BF00051981

[4] Barkman, J. J. 1958. Phytosociology and ecology of cryptogamic epiphytes. Assen, The Netherlands: Van Gorcum and Comp. N.V. - G.A. Hak and Dr. H.J. Prakke

[5] Rindi, F., Sherwood, A.R. and Guiry, M.D. 2009. Taxonomy and distribution of Trentepohlia and Printzina (Trentepohliales, Chlorophyta) in the Hawaiian Islands. Phycologia, 44,270-284.

http://dx.doi.org/10.2216/0031-8884(2005)44[270:TADOTA]2.0.CO;2

[6] Hariot P. 1889. Notes sur le genre Trentepohlia Martius. J. Bot. 3: 128-149.

[7] Printz H. 1939. Vorarbeiten zu einer Monographie der Trentepohliaceen. Nytt. Mag. Naturvbidensk. 80: 137-210.

[8] Fritsch, F.E. 1907. A general consideration of the subaerial and freshwater algal flora of Ceylon. Proceedings of Royal Society 79:197-254.

http://dx.doi.org/10.1098/rspb.1907.0016

[9] Islam, N. 1960. Some subaerial green algae from East Pakistan. Transactions of the American Microscopical Society 79:471-479

http://dx.doi.org/10.2307/3224132

[10] Neustupa, J. \& Anna, S. 2013. Distribution patterns of subaerial microalgae in two European regions. Plant Ecology and Evolution 146 (3): 279-289

http://dx.doi.org/10.5091/plecevo.2013.862

[11] Marmor L., Randlane T. 2007. Effects of road traffic on bark pH and epiphytic lichens in Tallinn. Folia Cryptogamica Estonica 43: 23-37

[12] Fritz Ö., Brunet J., Caldiz M. 2009. Interacting effects of tree characteristics on the occurrence of rare epiphytes in a Swedish beech forest area. The Bryologist 112: 488-505. http://dx.doi. org/10.1639/0007-2745-112.3.488

http://dx.doi.org/10.1639/0007-2745-112.3.488 
[13] Scarborough A.R., Keller H.W., Ely J.S. 2009. Species assemblages of tree canopy myxomycetes related to bark pH. Castanea 74: 93-104.

http://dx.doi.org/10.2179/08-020.1

[14] Neustupa J., Škaloud P. 2008. Diversity of subaerial algae and cyanobacteria on tree bark in tropical mountain habitats. Biologia 63: 806-812. http://dx.doi.org/10.2478/s11756-008-0102-3

[15] Freystein K., Reisser W., 2010. Green biofilms on tree barks: more than just algae. In: Seckbach J., Grube M. (eds) Symbioses and stress: 559-573.Heidelberg, Springer http://dx.doi.org/10.1007/978-90-481-9449-0_29

[16] Rindi, F., Allali, H.A., Lam, D.W., and López-Bautista, J.M. 2010. An overview of the biodiversity and biogeography of terrestrial green algae. Biodiversity Hotspots. Nova Science Publishers, New York, 105-122

[17] Rindi, F., Sherwood, A.R. and Guiry, M.D. 2009. Taxonomy and distribution of Trentepohlia and Printzina (Trentepohliales, Chlorophyta) in the Hawaiian Islands. Phycologia, 44,270-284. http://dx.doi.org/10.2216/0031-8884(2005)44[270:TADOTA]2.0.CO;2

[18] Asmida, I. 2012.Dissertation On Effects of Atmospheric Pollutants On Epiphytic Terrestrial Algae. Imperial College London, United Kingdom.

[19] John, D.M., Whitton, B.A \& Brook, A.J. 2002. The Freshwater Algal Floral of The British Isles. Cambridge University Press. London. 702pp.

[20] Lopez-Bautista,J.M., Rindi,F. \& Guiry, M.D. 2006. Molecular systematics of the subaerial green algal order Trentepohliale: an assessment based on morphological and molecular data. International journal of Systematics and Evolutionary Microbiology, 56, 1709-1715.

http://dx.doi.org/10.1099/ijs.0.63990-0

[21] Ellis, C.J. \& Coppins, B.J. 2007. Reproductive strategy and the compositional dynamics of crustose lichen communities on aspen (Populus tremula L.) in Scotland. The Lichenologist 39: 377-391 http://dx.doi.org/10.1017/S0024282907006937

[22] Lamit, L.J., Bowker, M.A., Holeski, L.M., Næsborg, R.R., Wooley, S.C., Zinkgraf, M., Lindroth, R.L., Whitham, T.G. \& Gehring, C.A. 2011. Genetically-based trait variation within a foundation tree species influences a dominant bark lichen. Fungal Ecology 4: 103-109 http://dx.doi.org/10.1016/j.funeco.2010.09.007

[23] John, D. M. 1988. Algal growths on buildings:a general review and methods of treatment. Biodeterior Abstr 2:81102

[24] Edward. J \& Lewis. J. 2012. Dissertation on Biomonitoring For Atmopsheric Nitrogen Pollution Using Epiphytic Lichens and Bryophytes. University of Nottingham

[25] Jönsson, A.M. 1998. Bark lesions on Beech (Fagus sylvatica) and their relation to epiphytes and site variables in Scania, South Sweden. Scandinavian Journal of Forest Research 13: 297-305

http://dx.doi.org/10.1080/02827589809382988

[26] Poikolainen, J. 2004. Mosses, epiphytic lichens and tree bark as biomonitors for air pollutants - specifically for heavy metals in Regional surveys. Oulu: Oulun Yliopisto. 64 p.

[27] Taylor ,K. , Woof ,C., Ineson ,P. et al . 1999. Variation in seasonal precipitation chemistry with altitude in the northern Pennines, UK. Environmental Pollution , 104, 1 -9

http://dx.doi.org/10.1016/S0269-7491(98)00161-4

[28] Thornber, C. S., Dimilla, P., Nixon, S. W. \& Mckinney, R. A. 2008. Natural and anthropogenic nitrogen uptake by bloom-forming macroalgae. Marine Pollution Bulletin, 56, 261-269.

http://dx.doi.org/10.1016/j.marpolbul.2007.10.031

[29] Poikolainen, J. 2004. Mosses, Epiphytic Lichens and Tree Bark as Biomonitors for Air pollutants - Specifically for Heavy Metals in Regional Surveys. Faculty of Science, Department of Biology, University of Oulu; The Finnish Forest Research Institute, Muhos Research Station, ISBN 951-42-7479-2, Oulu, Finland 
[30] Poikolainen, J. 2004. Mosses, Epiphytic Lichens and Tree Bark as Biomonitors for Air pollutants - Specifically for Heavy Metals in Regional Surveys. Faculty of Science, Department of Biology, University of Oulu; The Finnish Forest Research Institute, Muhos Research Station, ISBN 951-42-7479-2, Oulu, Finland 